\title{
Plasma prevalence of anti-N-methyl-d-aspartate receptor IgG antibodies in early stages of psychosis
}

\author{
Prevalência plasmática de anticorpos IgG antirreceptor \\ $\mathrm{N}$-metil-d-aspartato nos estágios iniciais de psicose
}

\author{
Camila Marcelino Loureiro (https://orcid.org/0000-0002-0239-5064) ${ }^{1}$ \\ Fabiana Corsi-Zuelli (https://orcid.org/0000-0001-9202-3987) ${ }^{2}$ \\ Helene Aparecida Fachim (https://orcid.org/0000-0003-3818-3167) ${ }^{3}$ \\ Rosana Shuhama (https://orcid.org/0000-0001-7626-7543) ${ }^{2}$ \\ Natália Mota de Souza Chagas (https://orcid.org/0000-0003-0984-9919) ${ }^{2}$ \\ Paulo Rossi Menezes (https://orcid.org/0000-0001-6330-3314) ${ }^{4}$ \\ Cristina Marta Del-Ben (https://orcid.org/0000-0003-0145-9975) ${ }^{2}$ \\ Paulo Louzada-Junior (https://orcid.org/0000-0003-2585-3870) ${ }^{1}$
}

${ }^{1}$ Departamento de Medicina Interna, Divisão de Imunologia Clínica, Faculdade de Medicina de Ribeirão Preto, Universidade de São Paulo (USP). Av. Bandeirantes 3900, Monte Alegre. 14049-900 Ribeirão Preto SP Brasil.

camila.loureiro@usp.br

${ }^{2}$ Departamento

de Neurociência e

Comportamento, Divisão de Psiquiatria, Faculdade de Medicina de Ribeirão Preto, USP. Ribeirão Preto SP Brasil.

${ }^{3}$ Departamento de Endocrinologia e

Metabolismo, Salford Royal Foundation Trust. Salford

Reino Unido.

${ }^{4}$ Departamento de Medicina Preventiva, Faculdade de Medicina, USP. São Paulo SP Brasil.
Abstract We investigated the feasibility of including plasma anti-NMDAR antibody screening in the assessment of first-episode psychosis patients in an early intervention programme in the Southern hemisphere. Anti-NMDAR IgG antibodies were assessed by ELISA in 166 patients (64.0\% men), 166 matched population-based controls and 76 patients' siblings (30.3\% men). Fisher's exact test and ANOVA were performed. Positive anti-NMDAR antibody patients were more often observed in bipolar disorder (10.0\%) than schizophrenia (2.4\%) or psychotic depression (3.1\%), although no significant differences were observed. Our results are not conclusive regarding the inclusion of plasma anti-NMDAR IgG antibodies in differential diagnostic protocols for psychosis.

Key words Antibodies anti-NMDAR, Bipolar disorder, Differential diagnosis, First-episode psychosis
Resumo Nós investigamos a viabilidade de incluir a pesquisa de anticorpos anti-NMDAR na avaliação de pacientes em primeiro episódio psicótico em um programa de intervenção precoce no Hemisfério Sul. Anticorpos IgG anti-NMDAR foram avaliados por ELISA em 166 pacientes (64,0\% homens), 166 controles de base populacional pareados e 76 irmãos (30,3\% homens). Foram realizados teste exato de Fisher e ANOVA. Os anticorpos anti-NMDAR positivos foram mais observados no transtorno afetivo bipolar $(10,0 \%)$ do que na esquizofrenia $(2,4 \%)$ ou depressão psicótica (3,1\%), embora não tenham sido observadas diferenças significativas. Nossos resultados não são conclusivos quanto à inclusão de anticorpos IgG anti-NMDAR no plasma em protocolos de diagnósticos diferenciais para psicose.

Palavras-chave Anticorpos anti-NMDAR, Transtorno afetivo bipolar, Diagnóstico diferencial, Primeiro episódio psicótico 


\section{Introduction}

Multiple factors may underlie the relationship between non-neurological autoimmune disorders and psychosis ${ }^{1}$, with particular interest being given to autoantibodies against the $\mathrm{N}$-methyl-d-aspartate receptor (NMDAR). In fact, this receptor plays an important role in psychosis ${ }^{2,3}$ and in a variety of neurological and non-neurological autoimmune diseases, including not only encephalitis ${ }^{4}$, but also systemic lupus erythematosus ${ }^{5}$ and autoimmune thyroid disease ${ }^{6}$. Patients affected by anti-NMDAR antibodies experience acute psychotic and other psychiatric manifestations, particularly at the onset of the illness ${ }^{7-11}$. The association between psychosis and peripheral autoimmune disorders has attracted attention and has led to recommendations that the presence of anti-NMDAR antibodies should be investigated routinely in first-episode psychosis (FEP) and in larger cohorts ${ }^{12,13}$.

However, the presence of anti-NMDAR autoantibodies has also been reported among healthy individuals ${ }^{14}$, resulting in uncertainty about their exact role in the neurobiology of psychosis. These discrepancies are being attributed to a variety of confounding factors, such as the duration of psychosis, substance misuse, psychotropic medication or the presence of other medical conditions ${ }^{15}$. Another unsolved question is related to the role that environmental factors may play in the immune response, given that the vast majority of studies have been carried out in the Northern hemisphere.

We investigated the plasma concentrations of anti-NMDAR IgG antibodies in adult Brazilian patients during the early stages of psychosis compared with their unaffected siblings and population-based controls in order to investigate if the prevalence of these antibodies in a sample from the South hemisphere would be similar to those observed in other parts of the globe. Moreover, we intended to verify the feasibility of plasma anti-NMDAR detection as a routine screening tool for FEP. We chose qualitative ELISA as an initial protocol based on previous reports that used this test to detect levels of anti-NMDAR antibodies in the screening of other clinical conditions, such as systemic lupus erythematous ${ }^{5,8}$. For the completion of the clinical assessment, we reviewed the medical records of patients who were positive for plasma anti-NMDAR antibodies to search for peculiarities in clinical presentations over a threeyear follow-up period.

\section{Methods}

\section{Participants}

This was a case-sibling-control study as part of an epidemiological study aimed to investigate the incidence and aetiology of psychosis in Ribeirão Preto catchment area (Brazil), the "Schizophrenia and Other Psychoses Translational Research: Environment and Molecular Biology" (STREAM) ${ }^{16}$, which is part of the multinational consortium "European Network of National Schizophrenia Networks Studying Gene-Environment Interactions" (EU-GEI) ${ }^{17}$ aimed at investigating the aetiology, mechanisms and prognosis of first episode psychosis.

The case sample was composed by incident FEP patients identified in the mental health services of the catchment area from $1^{\text {st }}$ April 2012 to $31^{\text {st }}$ March 2015. The sample was composed of (a) patients aged between 16 and 64 years old, in their first contact with mental health services due to psychotic symptoms; (b) their siblings; and (c) population-based controls, matched by sex and age with the patients, as described previously ${ }^{3}$.

For the recruitment of community-based controls, we considered the census blocks as defined by the Brazilian census bureau (IBGE, http://censo2010.ibge.gov.br/materiais/guia-docenso/operacao-censitaria.html). The census blocks were randomly selected in order to guarantee that all neighborhoods were equal in probability to be included in the study and to provide diversity in the social capital and vulnerability profiles.

The study was approved by the local Ethics committee. Informed consent was obtained from all individual participants included in the study. All procedures performed in studies involving human participants were in accordance with the ethical standards of the institutional and/or national research committee and with the Declaration of Helsinki and its later amendments or comparable ethical standards.

Participants were initially evaluated by the Structured Clinical Interview for the DSM-IV clinical version, SCID-CV ${ }^{18,19}$ to confirm any psychotic disorder.

All the patients included in the study were followed in an early intervention programme for psychosis at the Clinical Hospital of the Ribeirão Preto Medical School, University of São Paulo, Brazil, which is the regional reference for the specialized treatment of FEP and composed by inpatient and outpatient units. This service ap- 
plies a standardised protocol for differential diagnosis at the moment of admission ${ }^{20}$, including detailed medical and psychiatric history, physical examination, blood screening (full blood count, urea, creatine, glutamine-oxaloacetic transaminase (GOT), prothrombin time, thyroid-stimulating hormone (TSH), antinuclear antibody and syphilis serology $)^{21}$, besides urine tests to detect cannabis and cocaine metabolites, and neuroimaging exams (computed tomography and/ or magnetic resonance imaging). In face of any detected abnormalities in the initial screening, further exams were performed, according to the diagnostic hypothesis.

\section{Detection of anti-NMDAR antibodies}

Five milliliters of peripheral blood were collected from all participants in EDTA tubes. The samples were centrifuged for 10 minutes at 3,500 $\mathrm{rpm}, 4^{\circ} \mathrm{C}$ and the plasma was separated, aliquoted and stored in a freezer at $-80^{\circ} \mathrm{C}$. We used 50 $\mu \mathrm{L}$ of plasma for qualitative enzyme immunoassay of human NMDA IgG antibody via an enzyme-linked immunosorbent assay (ELISA), according to the manufacturer's instructions (MyBioSource, San Diego, CA). For calculation of the valence of human anti-NMDA IgG antibodies, each sample was compared with the control provided by the kit. The presence of anti-NMDAR IgG antibodies was considered positive when the optical density ratio (sample well/ control) was $\geq 2.1$. The coefficient of variation was $<15 \%$ for intra- and inter-assays. This assay has high sensitivity and excellent specificity for detection of human NMDAR IgG antibody.

\section{Clinical Reassessment}

The medical records of the patients' positive for anti-NMDAR IgG antibodies were reviewed over a three-year follow-up period to investigate the presence of eventual abnormalities in the clinical presentations at the moment of admission, complementary exams, longitudinal evolution and responses to treatment, that could be an indicative of impairment of immunological dysfunctions or other medical conditions.

\section{Statistical analysis}

Data were analysed using the SPSS, version 20.0 for Windows (SPSS Inc). Mean and standard deviations were calculated for continuous variables, and frequencies and percentages were calculated for categorical variables. Categorical and continuous variables were analysed using Fischer's exact test and one-way ANOVA, respectively. The alpha criterion was set to 0.05 .

\section{Results}

The sample was composed by 166 patients (64.0\% males), 84 of whom were diagnosed on the schizophrenia spectrum, 50 with bipolar disorder, and 32 with psychotic depression. In addition, 76 siblings (69.7\% females) and 166 paired controls (63.9\% males) were included. The mean age of the participants was $31.0 \pm 11.9$ years old, without significant differences observed among the groups $\left[\mathrm{F}_{(2,405)}=0.40 ; \mathrm{p}=0.674\right]$. The interval between psychosis onset and the blood collection varied from less than one month to 23 months (median=16.5).

Positivity for anti-NMDAR IgG antibodies was found in eight $(4.8 \%)$ patients, one sibling $(1.3 \%)$ and six $(3.6 \%)$ controls, without significant differences being observed among the groups (Fisher's exact test $=1.58, \mathrm{p}=0.483$ ). The presence of IgG antibodies was more often observed in patients with bipolar disorder $(n=5$, $10.0 \%)$ than in patients with schizophrenia $(\mathrm{n}=2$, $2.4 \%)$ or psychotic depression $(n=1,3.1 \%)$, but no statistically significant difference among the groups was observed (Fisher's exact test $=5.75$ $\mathrm{p}=0.172$ ).

Chart 1 shows a brief description of the clinical presentation and longitudinal evolution of the eight patients with positive plasma anti-NMDAR IgG antibodies. The duration of untreated psychosis ranged from less than one to more than 52 weeks (median=6). Four patients reported cannabis misuse. All patients, except one, underwent cranial computed tomography in the week of the first admission. Encephalon magnetic resonance was performed in six out of eight patients within 10 months of admission. No structural abnormalities were found in the neuroimaging assessments. Similarly, no registers of abnormalities were found regarding the medical histories or physical examinations in the patients' records. The initial screening indicated higher levels of TSH in two patients and higher levels of GOT in a third patient, but further investigations did not confirm thyroid or liver abnormalities, respectively. The longitudinal follow-up did not indicate any peculiarities of other medical conditions, confirming the initial diagnosis of a primary mental disorder. 
Chart 1. Demographic, clinical and imaging characteristics of patients in the early stages of psychosis.

\begin{tabular}{|c|c|c|c|c|c|}
\hline Demographics & Case vignette & $\begin{array}{c}\text { DUP } \\
\text { [weeks] }\end{array}$ & $\begin{array}{l}\text { Neuro- } \\
\text { imaging }\end{array}$ & $\begin{array}{c}\text { Initial } \\
\text { screening }\end{array}$ & $\begin{array}{c}\text { Interval } \\
\text { between } \\
\text { psychosis onset } \\
\text { and blood } \\
\text { collection } \\
\text { [months] }\end{array}$ \\
\hline M, 38 yo, brown & $\begin{array}{l}\text { Admitted in May } 2012 \text { due to elevated mood and } \\
\text { religious delusions that started two weeks before. } \\
\text { The patient remained hospitalized for } 16 \text { days, } \\
\text { being prescribed valproic acid and haloperidol. He } \\
\text { exhibited remission of the symptoms and remained } \\
\text { asymptomatic until a year later, when he needed a } \\
\text { new admission due to poor treatment adherence. } \\
\text { At this time, he presented with high self-esteem, } \\
\text { mystical delusions, reduced sleep, increased } \\
\text { psychomotricity, increased speech flow, and } \\
\text { incoherent speech. He was discharged after } 12 \text { days. } \\
\text { He was followed for the next two years, with good } \\
\text { adherence to the outpatient treatment and without } \\
\text { relapses. Final Diagnosis: Bipolar Disorder }\end{array}$ & 2 & $\begin{array}{l}\text { Normal } \\
{[\mathrm{CT} /} \\
\mathrm{MRI}]\end{array}$ & Normal & 21 \\
\hline F, 34 yo, black & $\begin{array}{l}\text { Admitted in July } 2012 \text { due to emotional } \\
\text { lability, expansive mood, distractibility, } \\
\text { increased psychomotricity, sexual disinhibition, } \\
\text { aggressiveness, irritability, reduced sleep and } \\
\text { behaviour suggestive of auditory and visual } \\
\text { hallucinations beginning two months before. } \\
\text { Patient was under treatment with sertraline, which } \\
\text { was prescribed due to complaints of depressed } \\
\text { mood, demotivation, thoughts of death and } \\
\text { suicidal ideation. The patient was also under } \\
\text { clinical follow-ups for hypothyroidism, obesity, } \\
\text { diabetes and systemic arterial hypertension. } \\
\text { Sertraline treatment was discontinued because the } \\
\text { condition was considered a possible manic episode } \\
\text { secondary to antidepressants, and haloperidol } \\
\text { and lithium carbonate were introduced. The } \\
\text { patient remained hospitalized for } 13 \text { days and was } \\
\text { discharged with partial remission. Over a four- } \\
\text { year follow-up period, the patient presented three } \\
\text { depressive episodes and two other admissions, both } \\
\text { due to manic episodes with psychotic symptoms. } \\
\text { Patient remained euthymic in the last year of the } \\
\text { follow-up, with monthly outpatient appointments, } \\
\text { under treatment with bupropion, quetiapine and } \\
\text { valproic acid. Final Diagnosis: Bipolar Disorder }\end{array}$ & 7 & $\begin{array}{l}\text { Normal } \\
{[\mathrm{CT} /} \\
\mathrm{MRI}]\end{array}$ & Normal & 23 \\
\hline
\end{tabular}

it continues

\section{Discussion}

In this study, we investigated the prevalence of plasma anti-NMDAR IgG antibodies in first episode psychosis and the feasibility of including the detection of these antibodies as a routine test for differential diagnosis in the early stag- es of psychosis. We also highlight the quality of our control sample. In our study, the number of attempts necessary to find an eligible volunteer was high (29 attempts per census) and the population-based methodology adopted in this study distinguishes from previous investigations besides strengthening the validity of our research. 
Chart 1. Demographic, clinical and imaging characteristics of patients in the early stages of psychosis.

\begin{tabular}{|c|c|c|c|c|c|}
\hline Demographics & Case vignette & $\begin{array}{c}\text { DUP } \\
\text { [weeks] }\end{array}$ & $\begin{array}{l}\text { Neuro- } \\
\text { imaging }\end{array}$ & $\begin{array}{c}\text { Initial } \\
\text { screening }\end{array}$ & $\begin{array}{c}\text { Interval } \\
\text { between } \\
\text { psychosis onset } \\
\text { and blood } \\
\text { collection } \\
\text { [months] }\end{array}$ \\
\hline F, 38 yo, white & $\begin{array}{l}\text { Admitted in November } 2012 \text { due to persecutory } \\
\text { and jealous delusions for at least six months. The } \\
\text { patient also complained of sadness, thoughts } \\
\text { of death and two suicide attempts. She sought } \\
\text { help from a psychiatrist and was medicated with } \\
\text { sertraline. Patient presented with restlessness, } \\
\text { psychomotor agitation and logorrhea after the } \\
\text { introduction of sertraline, being first diagnosed } \\
\text { as a manic episode secondary to antidepressants. } \\
\text { Regarding the premorbid personality, there was } \\
\text { a description of difficulties in interpersonal } \\
\text { relationships, with few friendships, and additional } \\
\text { impulsive, rigid and stubborn behaviour. The } \\
\text { patient was followed for at least four years. } \\
\text { Throughout the follow-up, the patient exhibited } \\
\text { bad responses to several pharmacological } \\
\text { treatments, poor adherence and reports of side } \\
\text { effects even at low doses. She was readmitted twice } \\
\text { due to depressive symptoms and suicidal thoughts. } \\
\text { Final Diagnosis: Recurrent Depressive Disorder } \\
\text { and Cluster B Personality Disorder }\end{array}$ & 29 & $\begin{array}{l}\text { Normal } \\
{[\mathrm{CT}]}\end{array}$ & Normal & 21 \\
\hline F, 30 yo, brown & $\begin{array}{l}\text { Admitted in April } 2013 \text { due to irritated mood, } \\
\text { physical aggression, decreased sleep, increased } \\
\text { psychomotricity and directed activity, and mystical } \\
\text { delusions, starting } 2 \text { days before. A year prior, the } \\
\text { patient underwent consultation with a psychiatrist } \\
\text { due to anxiety complaints, and sertraline was } \\
\text { prescribed; however, the patient did not use the } \\
\text { sertraline. She had systemic arterial hypertension } \\
\text { and was under treatment with enalapril. She } \\
\text { was given lithium carbonate and haloperidol. } \\
\text { The patient was discharged in } 10 \text { days after full } \\
\text { remission. She was referred for an outpatient } \\
\text { follow-up but attended only one appointment. } \\
\text { Final Diagnosis: Bipolar Disorder }\end{array}$ & $<1$ & $\begin{array}{l}\text { Normal } \\
{[\mathrm{CT} /} \\
\mathrm{MRI}]\end{array}$ & Normal & 1 \\
\hline
\end{tabular}

it continues

We found peripheral anti-NMDAR antibodies in $4.8 \%$ of our patients. However, these rates did not seem to have clinical relevance since the presence of plasma anti-NMDAR IgG antibodies was also observed in the controls $(3.6 \%)$ and in the patients' siblings $(1.3 \%)$. The rates of anti-NMDAR positivity observed in our study were in agreement with those previously described in both psychotic patients ${ }^{15,22}$ and healthy controls $^{14,23}$. Even without statistical significance, we identified that anti-NMDAR antibodies were more frequently present in bipolar disorder than in other conditions, a finding that was also in agreement with previous data ${ }^{24}$.

Increasing evidence demonstrate the importance of glutamatergic neurotransmission mediated by NMDARs not only in schizophrenia but also in mood disorders ${ }^{25,26}$. Bipolar disorders are characterized by altered levels of glutamate abnormalities in gene expression, concentration and NMDAR function ${ }^{27}$. An autoimmune process involving NMDAR was recently described 
Chart 1. Demographic, clinical and imaging characteristics of patients in the early stages of psychosis.

\begin{tabular}{|c|c|c|c|c|c|}
\hline Demographics & Case vignette & $\begin{array}{c}\text { DUP } \\
\text { [weeks] }\end{array}$ & $\begin{array}{l}\text { Neuro- } \\
\text { imaging }\end{array}$ & $\begin{array}{c}\text { Initial } \\
\text { screening }\end{array}$ & $\begin{array}{c}\text { Interval } \\
\text { between } \\
\text { psychosis onset } \\
\text { and blood } \\
\text { collection } \\
\text { [months] }\end{array}$ \\
\hline M,17 yo, brown & $\begin{array}{l}\text { Admitted in April } 2013 \text { and referred with the } \\
\text { diagnosis of a psychotic disorder due to multiple } \\
\text { substances. Two months before, he presented with } \\
\text { irritability, logorrhea, increased psychomotricity } \\
\text { followed by disorganized speech, persecutory } \\
\text { delusions, soliloquies and aggressive behaviour. } \\
\text { The patient reported daily cannabis use since the } \\
\text { age of } 13 \text { and sporadic use of cocaine since the } \\
\text { age of } 15 \text {. After four days of hospitalization, the } \\
\text { patient presented full remission. He was discharged } \\
\text { using haloperidol, valproic acid and lorazepam. } \\
\text { Patient did not adhere to the outpatient treatment, } \\
\text { and four months later, he was readmitted due to } \\
\text { increased energy, reduction in sleep requirements, } \\
\text { expansive mood, distractibility and hypersexual } \\
\text { behaviour. Even though he was only partially } \\
\text { remitted, he was discharged at the request of his } \\
\text { relatives on the 23rd day after admission. The } \\
\text { patient only attended the outpatient follow-up } \\
\text { once. Final Diagnosis: Bipolar Disorder }\end{array}$ & 5 & $\begin{array}{l}\text { Normal } \\
{[\mathrm{CT} /} \\
\mathrm{MRI}]\end{array}$ & $\begin{array}{l}\text { Increased } \\
\text { TSH }\end{array}$ & 15 \\
\hline M, 19 yo, black & $\begin{array}{l}\text { Admitted in July } 2013 \text { due to psychomotor } \\
\text { agitation, persecutions and behavioural } \\
\text { disorganization that started one month before. } \\
\text { Before being admitted to our psychiatric unit, the } \\
\text { patient stayed for } 15 \text { days in other departments, } \\
\text { where he was physically restrained and medicated } \\
\text { intramuscularly countless times with haloperidol. } \\
\text { The patient developed a condition suggestive of } \\
\text { malignant neuroleptic syndrome, with cervical } \\
\text { dystonia, tremors, sialorrhea, mental confusion, } \\
\text { lowering of consciousness and autonomic } \\
\text { instability, as well as increased CPK. At the time of } \\
\text { admission, the patient had persecutory delusions } \\
\text { and behaviour suggestive of auditory and visual } \\
\text { hallucinations. According to relatives, since the age } \\
\text { of } 12 \text {, the patient had been more introverted and } \\
\text { silent than other children, exhibiting schooling } \\
\text { difficulties and repeating the eighth grade twice. } \\
\text { He remained hospitalized for approximately one } \\
\text { month until partial remission of symptoms under } \\
\text { the treatment with risperidone. Over a three-year } \\
\text { follow-up period with monthly appointments, } \\
\text { the delusions and hallucinations remitted, but } \\
\text { social withdrawal, blunting affect and a certain } \\
\text { impairment in functionality remained. Final } \\
\text { Diagnosis: Schizophrenia }\end{array}$ & 4 & $\begin{array}{l}\text { Normal } \\
{[\mathrm{MRI}]}\end{array}$ & $\begin{array}{l}\text { Increased } \\
\text { TSH }\end{array}$ & 2 \\
\hline
\end{tabular}

it continues

as a possible biological correlation of the pathophysiology of bipolar disorders in a cohort of 60 manic patients, which showed high levels of autoantibodies against NR2 subunit ${ }^{28}$. Overall, our 
Chart 1. Demographic, clinical and imaging characteristics of patients in the early stages of psychosis.

\begin{tabular}{|c|c|c|c|c|c|}
\hline Demographics & Case vignette & $\begin{array}{c}\text { DUP } \\
\text { [weeks] }\end{array}$ & $\begin{array}{l}\text { Neuro- } \\
\text { imaging }\end{array}$ & $\begin{array}{c}\text { Initial } \\
\text { screening }\end{array}$ & \begin{tabular}{|c|} 
Interval \\
between \\
psychosis onset \\
and blood \\
collection \\
[months] \\
\end{tabular} \\
\hline M, 16 yo, brown & $\begin{array}{l}\text { Admitted in January } 2014 \text { due to irritability, } \\
\text { decreased need for sleep, persecutory, religious } \\
\text { and grandiose delusions, and risky behaviour that } \\
\text { started one year before, with periods of remission } \\
\text { and relapse. Patient had a history of cannabis use } \\
\text { and personality traits marked by stubbornness, } \\
\text { clutter and lack of acceptance of limits. Patient } \\
\text { remained hospitalized for } 33 \text { days and was } \\
\text { discharged under treatment with valproic acid and } \\
\text { risperidone. Patient remained asymptomatic for } \\
\text { at least one year, but he returned to cannabis use, } \\
\text { and a relapse occurred } 18 \text { months after the index } \\
\text { admission that featured grandiosity, psychomotor } \\
\text { agitation, increased energy, decreased need for } \\
\text { sleep, delusions and hallucinations. He was } \\
\text { readmitted and remained hospitalized for } 21 \text { days. } \\
\text { Patient was followed for the next year, without } \\
\text { relapse of the symptoms. Final Diagnoses: Bipolar } \\
\text { Disorder and Conduct Disorder }\end{array}$ & 52 & $\begin{array}{l}\text { Normal } \\
{[\mathrm{CT}]}\end{array}$ & Normal & 12 \\
\hline M, 20 yo, brown & $\begin{array}{l}\text { Admitted in June } 2014 \text { due to physical } \\
\text { heteroaggression, psychomotor agitation, } \\
\text { irritability and emotional lability, and behaviour } \\
\text { suggestive of auditory and visual hallucinations } \\
\text { that started more than one year before. He started } \\
\text { once-a-week cannabis use at the age of } 17 \text { and, } \\
\text { one year later, he started to exhibit delusional } \\
\text { speech and behaviour suggestive of visual and } \\
\text { auditory hallucinations, reduced sleep, logorrhea, } \\
\text { psychomotor agitation and aggression. At that } \\
\text { time, the patient was taken into consultation with } \\
\text { a psychiatrist and was prescribed haloperidol, with } \\
\text { full remission of symptoms. However, the patient } \\
\text { ceased using medication and presented with } \\
\text { relapses. From the beginning of the symptoms, the } \\
\text { patient continued to use cannabis and presented } \\
\text { residual psychotic symptoms. He stayed only two } \\
\text { days in our inpatient unit and was forwarded to the } \\
\text { referral service. Final Diagnosis: Schizophrenia }\end{array}$ & 26 & $\begin{array}{l}\text { Normal } \\
{[\mathrm{CT} /} \\
\mathrm{MRI}]\end{array}$ & $\begin{array}{l}\text { Increased } \\
\text { GOT }\end{array}$ & 18 \\
\hline
\end{tabular}

DUP: duration of untreated psychosis; CT: computed tomography; F: female; M: male; MRI: magnetic resonance imaging; TSH: thyroidstimulating hormone; GOT: glutamic-oxaloacetic transaminase; yo: years old.

results suggested that the presence of plasma anti-NMDAR antibodies in Brazilian participants exhibited a similar pattern to those observed worldwide.

Reviews of the medical records of the eight patients with positive anti-NMDAR antibodies did not indicate peculiarities in the initial clinical presentation, longitudinal evolution or treat- ment response; a finding that was similar to what has been described for children and adolescents in Australia ${ }^{29}$. Additionally, no abnormalities were found in the complementary blood or neuroimaging tests.

As we aimed to verify the feasibility of including anti-NMDAR antibody screening in the clinical protocol, we chose qualitative ELISA as an ini- 
tial test. In addition to being less expensive, this test does not require a great deal of professional experience $e^{30,31}$ and is widely used in the screening of clinical conditions, such as systemic lupus erythematous $^{5,8}$. Although indirect immunofluorescence is often considered the gold standard for monitoring autoimmune disease ${ }^{14,32}$, this method has been criticized for being less sensitive to the detection of anti-NMDAR antibodies ${ }^{22,33}$. Moreover, cell-based assays, considered reliable methods for detecting anti-NMDAR antibodies $^{34-36}$, have been shown to have low sensitivity to detect low titers of these antibodies ${ }^{37}$.

Positive anti-NMDAR antibodies in our large cohort Brazilian FEP patients, unaffected siblings and community-based controls may suggest that anti-NMDAR antibody represents an overall epiphenomenon rather than being relevant to the clinical presentation. Further studies should consider testing the validity, economic costs and clinical impact of different anti-NMDAR assay methods ${ }^{38}$, including cerebrospinal measurement, and their combination in the screening of anti-NMDAR antibodies in psychosis.

\section{Limitations}

Our study has some important limitations that need to be addressed. We did not specify which NMDAR epitope would be detected and the IgG-type antibodies anti-NMDAR was measured at a single time point only. Further, we did not collect cerebrospinal fluid samples. Despite that, we highlight a few important strengths that distinguish our research from previous investigations, including clinical data assessed by the DSM-IV diagnosis, inclusion of neuroimaging exams and the longitudinal follow-up of our patients. Second and the most important, we analysed these anti-NMDAR antibodies not only in a large sample of early stages of psychosis, but also their unaffected siblings and population-based controls.

Despite these limitations, we believe that these results would be useful for doctors in psychiatric emergency services who assist FEP patients and need to improve their knowledge about differential diagnostic in relation to psychosis.

\section{Conclusion}

We have shown that the prevalence of anti-NMDAR in Southern hemisphere seems to be similar to those observed in other regions of the globe $^{39}$. However, considering the anti-NMDAR positivity has also been observed in community-based controls, our findings do not support the inclusion of the measurement of plasma anti-NMDAR IgG antibodies by qualitative ELISA for the purposes of differential diagnosis in psychosis.

\section{Collaborations}

CM Loureiro contributed to the study design, analyzed data, drafted the initial manuscript and approved the final manuscript as submitted. F Corsi-Zuelli contributed to the study design and revised the manuscript. HA Fachim reviewed the study and approved the final manuscript as submitted. R Shuhama reviewed and obtained the ethical considerations. NMS Chagas helped to write the features of participants. PR Menezes, CM Del-Ben and P Louzada-Junior revised critically the manuscript, acquired the funding and approved the final manuscript as submitted.

\section{Acknowledgments}

The authors acknowledge Fundação de Amparo à Pesquisa do Estado de São Paulo (FAPESP) and Coordenação de Aperfeiçoamento de Pessoal de Nível Superior (CAPES) for the financial support.

\section{Funding}

This research was supported by FAPESP grants 2012/05178-0;2013/08216-2 (Center for Research in Inflammatory Disease), and was financed in part by CAPES - Finance Code 001. CM Loureiro is a recipient of a scholarship from CAPES. F Corsi-Zuelli, HA Fachim and R Shuhama are recipients of fellowships from FAPESP (grants 2016/12195-9; 2017/17480-6, 2015/02948-7; 2017/00624-5 and 2013/11167-3, respectively), PR Menezes (level 1B, 303815/2015-9), CMD-B (level 1C, 307492/2014-1) and P Louzada-Junior (level 2, 305797/2016-6) are recipients of fellowships from CNPq. The mentioned funding sources did not partake in the design, data collection, analysis and writing of this report. 


\section{References}

1. Cullen AE, Holmes S, Pollak TA, Blackman G, Joyce DW, Kempton MJ, Murray RM, McGuire P, Mondelli V. Associations Between Non-neurological Autoimmune Disorders and Psychosis: A Meta-analysis. Biol Psychiatry 2019; 85(1):35-48.

2. Najjar S, Steiner J, Najjar A, Bechter K. A clinical approach to new-onset psychosis associated with immune dysregulation: the concept of autoimmune psychosis. J Neuroinflammation 2018; 15(1):40.

3. Loureiro CM, Shuhama R, Fachim HA, Menezes PR, Del-Ben CM, Louzada-Junior P. Low plasma concentrations of $\mathrm{N}$-methyl- $\mathrm{d}$-aspartate receptor subunits as a possible biomarker for psychosis. Schizophr Res 2018; 202:55-63.

4. Kayser MS, Dalmau J. Anti-NMDA receptor encephalitis, autoimmunity, and psychosis. Schizophr Res 2016; 176(1):36-40.

5. Yang Y, Yuan C, Shen S-Q, Wang X-E, Mei Q-H, Jiang W-Q, Huang Q. Autoantibodies to NR2A Peptide of the Glutamate/NMDA Receptor in Patients with Seizure Disorders in Neuropsychiatric Systemic Lupus Erythematosus. Mediators Inflamm 2017; 2017:5047898.

6. Ikura T, Katsuse O, Chiba Y, Takahashi Y, Fujishiro H, Kamada A, Saito T, Hirayasu Y. Evaluation of titers of antibodies against peptides of subunits NR1 and NR2B of glutamate receptor by enzyme-linked immunosorbent assay in psychiatric patients with anti-thyroid antibodies. Neurosci Lett 2016; 628:201206.

7. Dalmau J, Gleichman AJ, Hughes EG, Rossi JE, Peng X, Lai M, Dessain SK, Rosenfeld MR, Balice-Gordon R, Lynch DR. Anti-NMDA-receptor encephalitis: case series and analysis of the effects of antibodies. Lancet Neurol 2008; 7(12):1091-1098.

8. Gono T, Kawaguchi Y, Kaneko H, Nishimura K, Hanaoka M, Kataoka S, Okamoto Y, Katsumata Y, Yamanaka H. Anti-NR2A antibody as a predictor for neuropsychiatric systemic lupus erythematosus. Rheumatology 2011; 50(9):1578-1585

9. Hirohata S, Arinuma Y, Yanagida T, Yoshio T. Bloodbrain barrier damages and intrathecal synthesis of anti-N-methyl-D-aspartate receptor NR2 antibodies in diffuse psychiatric/neuropsychological syndromes in systemic lupus erythematosus. Arthritis Res Ther 2014; 16(2):R77.

10. Sciascia S, Bertolaccini ML, Roccatello D, Khamashta MA, Sanna G. Autoantibodies involved in neuropsychiatric manifestations associated with systemic lupus erythematosus: a systematic review. J Neurol 2014; 261(9):1706-1714.

11. Lennox BR, Palmer-Cooper EC, Pollak T, Hainsworth J, Marks J, Jacobson L, Lang B, Fox H, Ferry B, Scoriels L, Crowley H, Jones PB, Harrison PJ, Vincent A, PPiP study team. Prevalence and clinical characteristics of serum neuronal cell surface antibodies in first-episode psychosis: a case-control study. Lancet Psychiatry 2017; 4(1):42-48.

12. Chapman MR, Vause HE. Anti-NMDA receptor encephalitis: diagnosis, psychiatric presentation, and treatment. Am J Psychiatry 2011; 168(3):245-251.
13. van de Riet EH, Schieveld JN. First-onset psychosis, anti-NMDAR encephalitis, schizophrenia and Consultation-Liaison psychiatry. Gen Hosp Psychiatry 2013; 35(4):442-423.

14. Hammer C, Stepniak B, Schneider A, Papiol S, Tantra M, Begemann M, Sirén A-L, Pardo LA, Sperling S, Jofrry SM, Gurvich A, Jensen N, Ostmeier K, Lühder F, Probst C, Martens H, Gillis M, Saher G, Assogna F, Spalletta G, Stöcker W, Schulz TF, Nave K-A, Ehrenreich $\mathrm{H}$. Neuropsychiatric disease relevance of circulating anti-NMDA receptor autoantibodies depends on blood-brain barrier integrity. Mol Psychiatry 2014; 19(10):1143-1149.

15. Pearlman DM, Najjar S. Meta-analysis of the association between $\mathrm{N}$-methyl-d-aspartate receptor antibodies and schizophrenia, schizoaffective disorder, bipolar disorder, and major depressive disorder. Schizophr Res 2014; 157(1-3):249-258.

16. Jongsma HE, Gayer-Anderson C, Lasalvia A, Quattrone D, Mulè A, Szöke A, Selten J-P, Turner C, Arango C, Tarricone I, Berardi D, Tortelli A, Llorca P-M, Haan L, Bobes J, Bernardo M, Sanjuán J, Santos JL, Arrojo M, Del-Ben CM, Menezes PR, Velthorst E, Murray RM, Rutten BP, Jones PB, van Os J, Morgan C, Kirkbride JB, European Network of National Schizophrenia Networks Studying Gene-Environment Interactions Work Package 2 (EU-GEI WP2) Group. Treated Incidence of Psychotic Disorders in the Multinational EU-GEI Study. JAMA Psychiatry 2018; 75(1):36.

17. European Network of National Networks studying Gene-Environment Interactions in Schizophrenia (EU-GEI). Identifying Gene-Environment Interactions in Schizophrenia: Contemporary Challenges for Integrated, Large-scale Investigations. Schizophr Bull 2014; 40(4):729-736.

18. Del-Ben CM, Vilela JAA, Crippa JA de S, Hallak JEC, Labate CM, Zuardi AW. Confiabilidade da "Entrevista Clínica Estruturada para o DSM-IV - Versão Clínica" traduzida para o português. Rev Bras Psiquiatr 2001; 23(3):156-159.

19. First MB, Spitzer RL, Gibbon M, Williams JBW. Structured Clinical Interview for DSM-IV-TR Axis I Disorders, Clinical Version (SCID-CV). New York: Biometrics Research, New York State Psychiatric Institute; 1997.

20. Del-Ben CM, Rufino ACTBF, Azevedo-Marques JM, Menezes PR. Differential diagnosis of first episode psychosis: importance of optimal approach in psychiatric emergencies. Rev Bras Psiquiatr 2010; 32(Supl. 2):S78-S86.

21. Mantovani C, Louzada-Junior P, Nunes EA, Figueiredo FP, Oliveira GR, Del-Ben CM. Antinuclear antibodies testing as a routine screening for systemic lupus erythematosus in patients presenting first-episode psychosis. Early Interv Psychiatry 2012; 6(3):322325.

22. Witte LD, Hoffmann C, van Mierlo HC, Titulaer MJ, Kahn RS, Martinez-Martinez P, European Consortium of Autoimmune Mental Disorders (CAIMED). Absence of N-Methyl-D-Aspartate Receptor IgG Autoantibodies in Schizophrenia: The Importance of Cross-Validation Studies. JAMA Psychiatry 2015; 72(7):731-733. 
23. Steiner J, Bogerts B. N-Methyl-d-aspartate receptor autoantibodies in schizophrenia and affective disorders. Schizophr Res 2015; 162(1-3):291.

24. León-Caballero J, Pacchiarotti I, Murru A, Valentí M, Colom F, Benach B, Pérez V, Dalmau J, Vieta E. Bipolar disorder and antibodies against the $\mathrm{N}$-methyl-d-aspartate receptor: A gate to the involvement of autoimmunity in the pathophysiology of bipolar illness. Neurosci Biobehav Rev 2015; 55:403-412.

25. Maletic V, Raison C. Integrated neurobiology of bipolar disorder. Front Psychiatry 2014; 5:98.

26. Rosenthal-Simons A, Durrant AR, Heresco-Levy U. Autoimmune-induced glutamatergic receptor dysfunctions: conceptual and psychiatric practice implications. Eur Neuropsychopharmacol 2013; 23(12):1659-1671.

27. Ghasemi M, Phillips C, Trillo L, De Miguel Z, Das D, Salehi A. The role of NMDA receptors in the pathophysiology and treatment of mood disorders. Neurosci Biobehav Rev 2014; 47:336-358.

28. Dickerson F, Stallings C, Vaughan C, Origoni A, Khushalani S, Yolken R. Antibodies to the glutamate receptor in mania. Bipolar Disord 2012; 14(5):547-553.

29. Pathmanandavel K, Starling J, Merheb V, Ramanathan S, Sinmaz N, Dale RC, Brilot F. Antibodies to surface dopamine-2 receptor and $\mathrm{N}$-methyl-D-aspartate receptor in the first episode of acute psychosis in children. Biol Psychiatry 2015; 77(6):537-547.

30. Patel D, Egner W, Gleeson D, Wild G, Ward A. Detection of serum M2 anti-mitochondrial antibodies by enzyme-linked immunosorbent assay is potentially less specific than by immunofluorescence. Ann Clin Biochem 2002; 39(Pt 3):304-307.

31. Rondeel JM. Immunofluorescence versus ELISA for the detection of antinuclear antigens. Expert Rev Mol Diagn 2002; 2(3):226-232.

32. Schou M, Sæther SG, Borowski K, Teegen B, Kondziella D, Stoecker W, Vaaler A, Reitan SK. Prevalence of serum anti-neuronal autoantibodies in patients admitted to acute psychiatric care. Psychol Med 2016; 46(16):3303-3313.

33. Steiner J, Walter M, Glanz W, Sarnyai Z, Bernstein HG, Vielhaber S, Kästner A, Skalej M, Jordan W, Schiltz K, Klingbeil C, Wandinger K-P, Bogerts B, Stoecker W. Increased prevalence of diverse N-methyl-D-aspartate glutamate receptor antibodies in patients with an initial diagnosis of schizophrenia: specific relevance of IgG NR1a antibodies for distinction from N-methyl-D-aspartate glutamate receptor encephalitis. JAMA Psychiatry 2013; 70(3):271-278.
34. Dahm L, Ott C, Steiner J, Stepniak B, Teegen B, Saschenbrecker S, Hammer C, Borowski K, Begemann M, Lemke S, Rentzsch K, Probst C, Martens H, Wienands J, Spalletta G, Weissenborn K, Stöcker W, Ehrenreich H. Seroprevalence of autoantibodies against brain antigens in health and disease. Ann Neurol 2014; 76(1):82-94.

35. Ehrenreich H. Autoantibodies against the N-Methyl-d-Aspartate Receptor Subunit NR1: Untangling Apparent Inconsistencies for Clinical Practice. Front Immunol 2017; 8:181.

36. Komorowski L, Stoecker W, Fraune J, Probst C. Letter to the editor re: "Pitfalls in the detection of N-methyl-d-aspartate-receptor (NMDA-R) antibodies" accurate evaluation of anti-NMDA-R cell-based assay avoids reporting of false positive results. Clin Biochem 2017; 50(7-8):458-459.

37. Jézéquel J, Rogemond V, Pollak T, Lepleux M, Jacobson L, Gréa H, Iyegbe C, Kahn R, McGuire P, Vincent A, Honnorat J, Leboyer M, Groc L. Techniques and Methods Cell-and Single Molecule-Based Methods to Detect Anti-N-Methyl-D-Aspartate Receptor Autoantibodies in Patients With First-Episode Psychosis From the OPTiMiSE Project. Biol Psychiatry 2017; 82(10):766-772.

38. Sinmaz N, Amatoury M, Merheb V, Ramanathan S, Dale RC, Brilot F. Autoantibodies in movement and psychiatric disorders: updated concepts in detection methods, pathogenicity, and CNS entry. Ann NY Acad Sci 2015; 1351:22-38.

39. Pollak TA, McCormack R, Peakman M, Nicholson TR, David AS. Prevalence of anti-N-methyl-d-aspartate (NMDA) antibodies in patients with schizophrenia and related psychoses: a systematic review and meta-analysis. Psychol Med 2014; 44(12):2475-2487.

Article submitted 19/03/2019

Approved 05/05/2019

Final version submitted 07/05/2019

Chief Editors: Romeu Gomes, Antônio Augusto Moura da Silva 